\title{
Use of osmotic solutions for inhibition of sunflower seed germination in blotter test
}

\author{
Beatriz Alemonge de S. Falleiro ${ }^{1}$, Pollyne Borborema A. de Almeida ${ }^{2}$, Wirton M. Coutinho ${ }^{3}$, Nelson D. \\ Suassuna $^{3}$ \& Leimi Kobayasti ${ }^{1}$
}

${ }^{1}$ Faculdade de Agronomia e Medicina Veterinária, Universidade Federal do Mato Grosso UFMT, 78060-900, Cuiabá, MT, Brazil; ${ }^{2}$ Departamento de Biologia, Universidade Estadual da Paraíba, 58429-500, Campina Grande, PB, Brazil; ${ }^{3}$ Embrapa Algodão, 58107-720, Campina Grande, PB, Brazil

Author for correspondence: Wirton M. Coutinho, e-mail: wirton@cnpa.embrapa.br

\begin{abstract}
The aim of this work was to investigate the feasibility of using a water restriction technique with osmotic solutes to control sunflower (Helianthus annuus L.) seed germination in blotter tests. The effects of water potential (-0.8 MPa - Megapascal, $-1.0 \mathrm{MPa}$, -1.2 $\mathrm{MPa}$ and $-1.4 \mathrm{MPa}$ ) of substrates osmotically modified with sodium chloride or mannitol were evaluated for seed germination, radicle length and mycoflora present in the samples. The effects of levels of osmotic potentials ranging from $-0.35 \mathrm{MPa}$ to $-1.4 \mathrm{MPa}$ were also investigated on mycelial growth of the fungi Alternaria alternata and Alternaria zinniae on PDA medium. All osmotic potentials were able to inhibit or to retard seed germination to the extent that seed examination in stereomicroscope became easier without affecting seed mycoflora associated with the seeds. Mycelial growth of $A$. alternata was stimulated by all osmotic solutes tested, while mycelial growth of $A$. zinniae was stimulated by mannitol and reduced by all $\mathrm{NaCl}$ osmotic potential levels used.
\end{abstract}

Key words: Helianthus annuus, sodium chloride, mannitol.

\section{RESUMO}

Uso de solutos osmóticos na inhibição da germinação de sementes de girasol em testes de sanidade ("blotter test")

Neste trabalho, o objetivo foi avaliar o uso de solutos osmóticos em testes de sanidade de sementes de girassol pelo método de incubação em papel de filtro com restrição hídrica do substrato, induzida pela adição de cloreto de sódio e manitol, em relação à germinação de sementes, comprimento de radícula e a detecção da micoflora associada às sementes ou plântulas. Foram testados os níveis de restrição hídrica de -0,8 MPa (Megapascal), -1.0 MPa, -1,2 MPa e -1,4 MPa. O crescimento micelial in vitro dos fungos Alternaria alternata e Alternaria zinniae foi também avaliado em meio de BDA osmoticamente modificado com os mesmos solutos e níveis de restrição, variando de -0,35 MPa (BDA padrão) a -1,4 MPa. A restrição hídrica do substrato de papel induzida pelos solutos testados, nos níveis avaliados, reduziu a germinação das sementes e o comprimento de radícula e não interferiu na detecção dos fungos. A restrição hídrica do meio BDA, induzida por manitol nos diferentes potenciais osmóticos testados, estimulou o crescimento micelial tanto de $A$. alternata quanto de $A$. zinniae, enquanto que o meio modificado com $\mathrm{NaCl}$ estimulou apenas o crescimento micelial de $A$. alternata, afetando adversamente o crescimento micelial de $A$. zinniae.

Palavras-chave: Helianthus annuus, cloreto de sódio, manitol.

\section{INTRODUCTION}

The fast germination of sunflower (Helianthus annus L.) seeds on blotter health tests interferes in the detection of seed-borne fungi. The fast-growing radicle may cause cross contamination between seeds and may make it difficult to identify the fungi associated with germinated seeds by stereomicroscope examination. Inhibition of seed germination of dicotyledonous species such as common bean and soybean (Machado et al., 2008) is routinely done by adding 2,4-dicholorophenoxyacetic acid (sodium salt formulation of 2,4-D) to water used to moisten the blotter in seed health tests (Hagborg et al., 1950; Neergaard, 1979; Machado, 1988). However, due to the carcinogenic nature of 2,4-D, other protocols have been developed, using blotter moistened with osmotic solutions adjusted at different osmotic potentials.

The use of osmotic solution instead of water plus 2,4 D has been successfully applied to inhibit or retard seed germination of monocotyledonous and dicotyledonous species, such as rice, bean, maize and wheat in blotter test (Coutinho et al., 2001; Farias et al., 2003; Machado et al., 2003, 2008). The technique is based on the manipulation of seed water relations by changing the water used to moisten the blotter to osmotic solutions prepared with ionic and non-ionic solutes. Under that condition water uptake by seeds is controlled and the germination process is inhibited or reduced. Seed germination in blotter test can be inhibited or retarded using compounds such as salts and sugars (Machado et al., 2008). 
Although fungal development may vary greatly according to the osmotic potentials of substrates, the fungi are likely to be affected only at higher osmotic potentials. At potentials in the range of -0.3 to $-2.0 \mathrm{MPa}$, the growth of Botrytis cinerea, Alternaria alternata, Aspergillus niger, Cryphonectria parasitica, Fusarium moniliforme and Fusarium graminearum was actually stimulated (Adebayo \& Harris, 1971; Wearing \& Burgess, 1979; Subbarao et al., 1993; Gao \& Shain, 1995; Alam et al., 1996). Growth of Colletotrichum lindemunthianum, Bipolaris sorokiniana, Acremonium strictum, Drechslera oryzae, Phoma sorghina, Pyricularia grisea, Gerlachia oryzae, Fusarium oxysporum f.sp. phaseoli, Macrophomina phaseolina and Rhizoctonia solani increased progressively as the osmotic potential increased in the range varying from $-0.3 \mathrm{MPa}$ to $-1.0 \mathrm{MPa}$ (Carvalho et al., 2001; Farias et al., 2004; Teixeira et al., 2005; Machado et al., 2008). The effect was independent of the solute type, either salt or sucrose, in the agar medium. The objective in this work was to investigate the use of water restriction technique by using osmotic solutes mannitol and sodium chloride $(\mathrm{NaCl})$ as an alternative means to inhibit seed germination or to reduce radicle elongation of sunflower seeds in seed blotter health tests.

\section{MATERIAL AND METHODS}

Effects of water restriction on the germination of seeds and on the recovery of common fungi associated with sunflower seeds

Three seed bulks of sunflower (Helianthus annuus L.), cv Embrapa 122-V2000, were used: lot 1, obtained from Escritório de Negócios de Dourados (SNT / Embrapa - Dourados), was produced during the 2005/2006 season, and lots 2 and 3, obtained from Embrapa Soja, were produced, respectively, during the 2005/2006 and 2006/2007 seasons. Sample selection was based on the percentage of germination and vigor and levels of fungi associated with seeds, as determined by preliminary tests.

Technically pure products mannitol and $\mathrm{NaCl}$ were provided by their manufacturers in Brazil. The concentrations of osmotic compounds were adjusted to provide osmotic potentials that varied in the range of $-0.8 \mathrm{MPa}$ to -1.4 MPa. The quantities of each solute were calculated with the software SPPM (Michel \& Radcliffe, 1995) and are indicated in Table 1.

Blotter test using distilled water (control): Seeds were evenly spaced on sterilized filter paper (three discs) moistened with sterile water in $15 \mathrm{~cm}$ diameter Petri dishes at the density of 25 seeds/dish. The seeds were incubated at $20^{\circ} \mathrm{C}$ under cool fluorescent lamps with a 12-hour photoperiod for seven days.

Blotter test using osmotic solutions: Seeds were evenly spaced on sterilized filter paper (three discs) moistened with sterile osmotic solutions at $-0.8 \mathrm{MPa},-1.0$ $\mathrm{MPa},-1.2 \mathrm{MPa}$, and -1.4 MPa, prepared as indicated in Table 1, in $15 \mathrm{~cm}$ diameter Petri dishes at the density of 25 seeds/dish. The seeds were incubated as described for the blotter test and moistened with distilled water (control).

The percentage of germinated seeds, radicle length and percentage of fungal occurrence on seeds was recorded at the end of the incubation period. Fungal examination was done with a stereomicroscope of $40 \mathrm{x}$ magnification and with a compound microscope whenever required.

\section{Effects of water restriction on mycelial growth of seed- borne fungi of sunflower on agar substrate}

Pure cultures of two isolates of Alternaria zinniae Ellis and two isolates of Alternaria alternata ( $\mathrm{Fr}$.) Keissler were obtained from colonies grown on sunflower seeds submitted to blotter test. Fungal cultures were grown on PDA medium for seven days with incubation at temperature of $25^{\circ} \mathrm{C}$, and alternating light/dark regime of 12 hours.

Based on the results of the first experiment, fungal growth was evaluated on PDA medium containing either mannitol or sodium chloride $(\mathrm{NaCl})$. Osmotic potentials ranging from -0.8 to $-1.4 \mathrm{MPa}$ were used. Amounts of osmotic solutes that were incorporated into the PDA medium were calculated using the software SPPM (Michel $\&$ Radcliffe, 1995) and are indicated in Table 1. The osmotic potential of the PDA medium was estimated to $-0.35 \mathrm{MPa}$ (Sommers et al., 1970; Wearing \& Burgess, 1979).

Inoculum of each fungus consisted of $0.5 \mathrm{~cm}$ diameter agar discs cut from the edge of 6-8 day-old colonies and placed on the center of $9 \mathrm{~cm}$ Petri dishes. Dishes were placed in an incubator at $25^{\circ} \mathrm{C}$ under cool fluorescent lamps with a 12-hour photoperiod for seven days. Mycelial

TABLE 1 - Amounts of chemicals used to prepare osmotic solutions and to amend PDA medium at different osmotic potentials

\begin{tabular}{lcccc}
\hline \hline \multirow{2}{*}{ Osmotic potential (MPa) } & \multicolumn{2}{c}{ g.L $\mathbf{L}^{-1}$ distilled water } & \multicolumn{2}{c}{ g.L $^{\mathbf{1}}$ PDA $^{\mathbf{2}}$} \\
\cline { 2 - 5 } & $\mathbf{N a C l}$ & Mannitol & NaCl & Mannitol \\
\hline-0.8 & 10.23 & 58.79 & 5.71 & 33.10 \\
-1.0 & 12.75 & 73.49 & 8.22 & 47.75 \\
-1.2 & 15.37 & 88.24 & 10.84 & 62.46 \\
-1.4 & 18.00 & 102.92 & 13.45 & 77.12 \\
\hline
\end{tabular}

${ }^{1}$ Molality concentrations calculated at $20^{\circ} \mathrm{C}$.

${ }^{2}$ Molality concentrations calculated at $25^{\circ} \mathrm{C}$. 
growth of both fungi was measured taking the average of two diameters of colonies at right angles to each other after six days of incubation.

\section{Statistical design and analysis}

Experiment 1. The experimental design was completely randomized with treatments organized in a factorial scheme: blotter test moistened with two osmotic solutes $\mathrm{x}$ four osmotic potentials, including one additional treatment (blotter test moistened with distilled water) with four replications.

No variance homogeneity was verified by using Bartlett test for seed germination and radicle length variables, so data were analyzed using a generalized linear model, assuming a binomial response variable and a logit link function (only seed germination). Models were fitted to seed germination and radicle length data. Multivariate analysis was performed on each seed lot to assess the effect of osmotic potentials on seed mycoflora by using Wilk's Lambda Criteria. Statistical analyses were conducted using SAS version 9.1.3 (SAS Institute Inc. Cary, NC, USA).

Experiment 2. The experimental design was completely randomized with treatments organized in a factorial scheme: two osmotic solutes $\mathrm{x}$ four osmotic potentials used for amended PDA medium $\mathrm{x}$ two (isolates) + one additional treatment (PDA medium) with four replications. No variance homogeneity was verified by using Bartlett test, so data were analyzed using a generalized linear model. Models were fitted separately to mycelial growth data of each fungus. Statistical analyses were conducted using SAS version 9.1.3 (SAS Institute Inc. Cary, NC, USA).

\section{RESULTS AND DISCUSSION}

Seed germination, radicle length and recovery of common fungi associated with sunflower seeds

There were significant differences between the results of blotter test moistened with distilled water (control) and osmotic solutions for all sunflower seed lots. The mean germination rates of seeds in the control treatment were 0.92 (lot 1), 0.91 (lot 2) and 0.86 (lot 3) while radicle length was $2.7 \mathrm{~cm}$ (lot 1), $3.9 \mathrm{~cm}$ (lot 2) and $3.2 \mathrm{~cm}$ (lot 3 ). Both seed germination and radicle length of sunflower seeds were strongly reduced in seed blotter moistened with osmotic solutions at different osmotic potentials. Germination rates and radicle length decreased as osmotic potentials increased (Figures 1 and 2). Similar results were observed by Machado et al. $(2007,2008)$ with cotton, rice and common bean seeds submitted to blotter moistened with osmotic solutions prepared with $\mathrm{NaCl}, \mathrm{KCl}$ and mannitol solutes.

The longer period of seed pre-germination on substrates osmotically adjusted by ionic or non-ionic solutes is explained by the decrease in seed metabolism, which is affected by the lower water availability for reserve digestion and translocation of metabolized products (Campos \& Assunção, 1990; Braccini et al., 1996; Bewley \& Black, 1994; Taiz \& Zeiger, 2004). Thus, osmotic potential induced by solutes acts by reducing the speed of germination or by restricting germination rate, affecting cellular elongation and wall synthesis (Wenkert et al., 1978; Adebuyi et al., 1981). Salts such as $\mathrm{NaCl}$ can be assimilated by plant tissues at toxic levels, causing damage to seed germination and to radicle elongation (Van Der Moezel \& Bell, 1987; Braccini et al., 1996). These products can also inhibit the activity or synthesis of hydrolytic enzymes, which are required for seed germination (Campos \& Assunção, 1990; Machado et al., 2008).

The effect of water restriction on the mycoflora of sunflower seeds was based on the occurrence of the species detected by the blotter test method in three seed lots (Table 2). By that method the following species were detected: Alternaria alternata, Aspergillus flavus, Botrytis cinerea, Cladosporium cladosporioides, Penicillium spp., Aspergillus ochraceus and Aspergillus glaucus. In all seed lots tested, the occurrence of these fungi was not adversely affected at any osmotic potential regardless of the osmotic compounds used. The percentage of fungi recovered on blotter substrate amended with osmotic solution was significantly higher in lots 2 and 3 (mannitol) and lot $3(\mathrm{NaCl})$ when compared to the blotter test moistened with distilled water. These results may be related to the fact that the mycoflora associated with the sunflower seeds used in this study had been formed by fungi whose growth is greater in dry conditions than that of those induced by seed blotter test moistened with osmotic solutions. In addition, mannitol is a sugar that may be used as an energy source by those fungi.

Another aspect that must be considered in this work is the fact that blotter test moistened with osmotic solutions provides conditions to inhibit or to retard sunflower seed germination, making it easier to identify and recover the fungi associated with seeds examined in the stereomicroscope. In similar studies, Machado et al. (2003) and Machado et al. (2008) also verified the efficacy of the osmotic solutions prepared with mannitol, $\mathrm{KCl}$ and $\mathrm{NaCl}$ in inhibiting or suppressing seed germination of soybean, rice and common in blotter test. This procedure also made it easier to identify and recover fungi associated with the seeds.

\section{Mycelial growth on osmotically modified agar medium}

There were significant differences between mycelial growth of A. alternata and A. zinniae isolates $(\mathrm{P}<0.05)$ when compared on PDA medium (control treatment) and PDA amended with mannitol or $\mathrm{NaCl}$. The mycelial growth of $A$. alternata on PDA was $5.9 \mathrm{~cm}$ (isolate 1) and $4.8 \mathrm{~cm}$ (isolate 2), while for A. zinniae it was 5.8 (isolate 1) and 4.9 (isolate 2). Mycelial growth of 

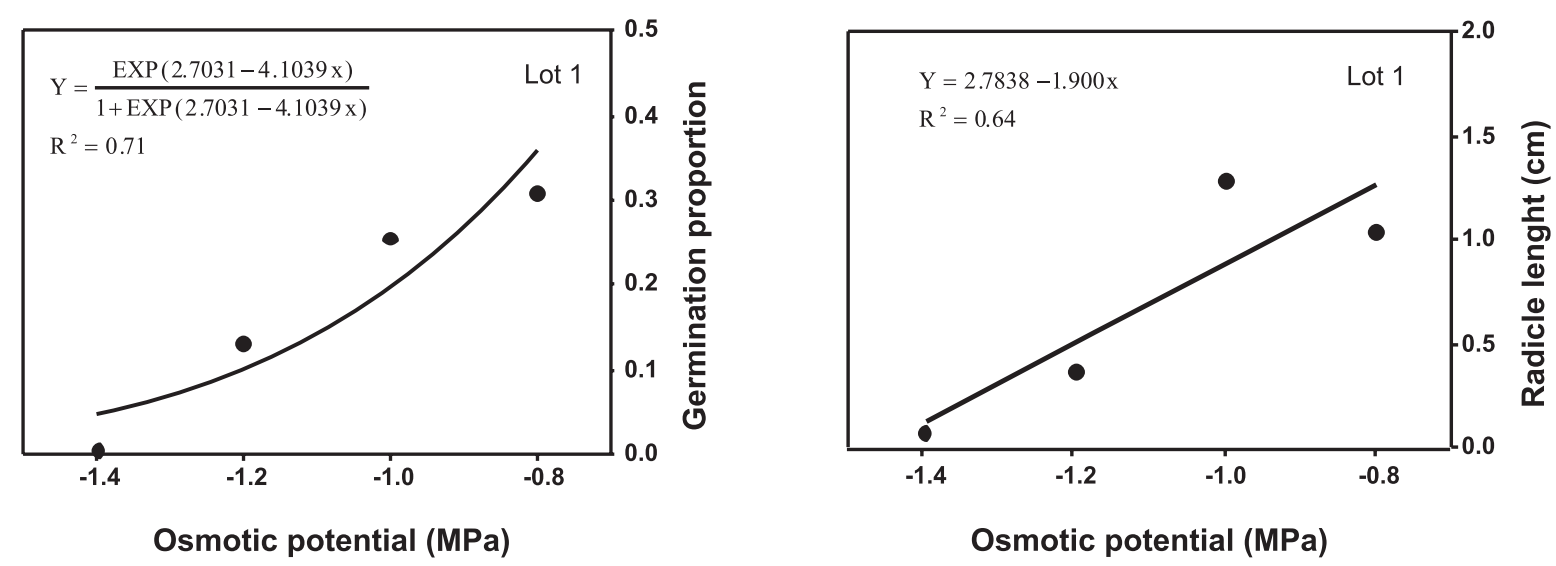

Osmotic potential (MPa)
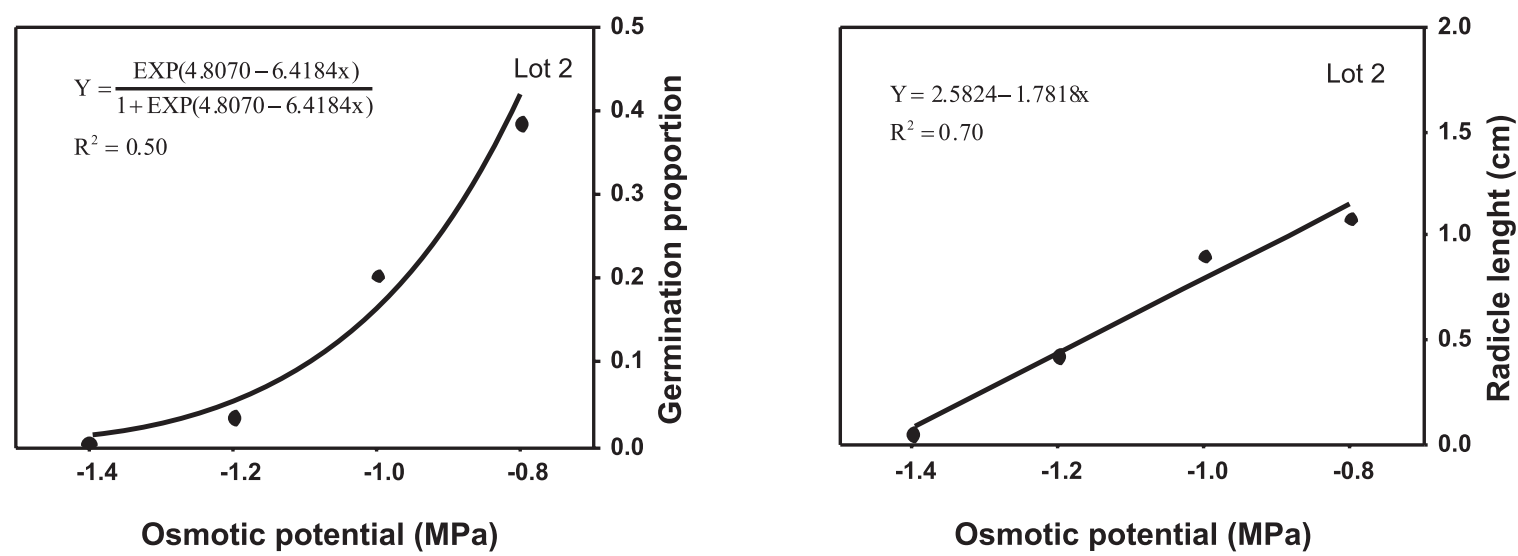

Osmotic potential (MPa)
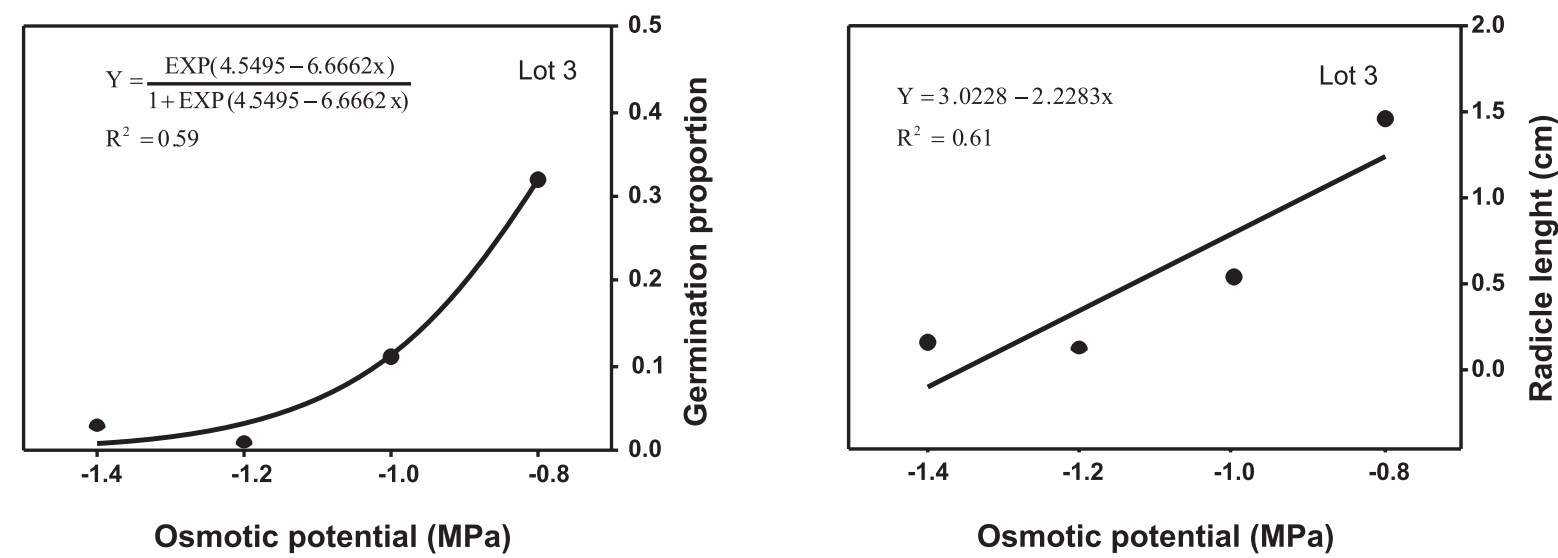

FIGURE 1 - Radicle length and germination proportion of three lots of sunflower seeds submitted to seed blotter moistened with osmotic solutions at different osmotic potentials. 

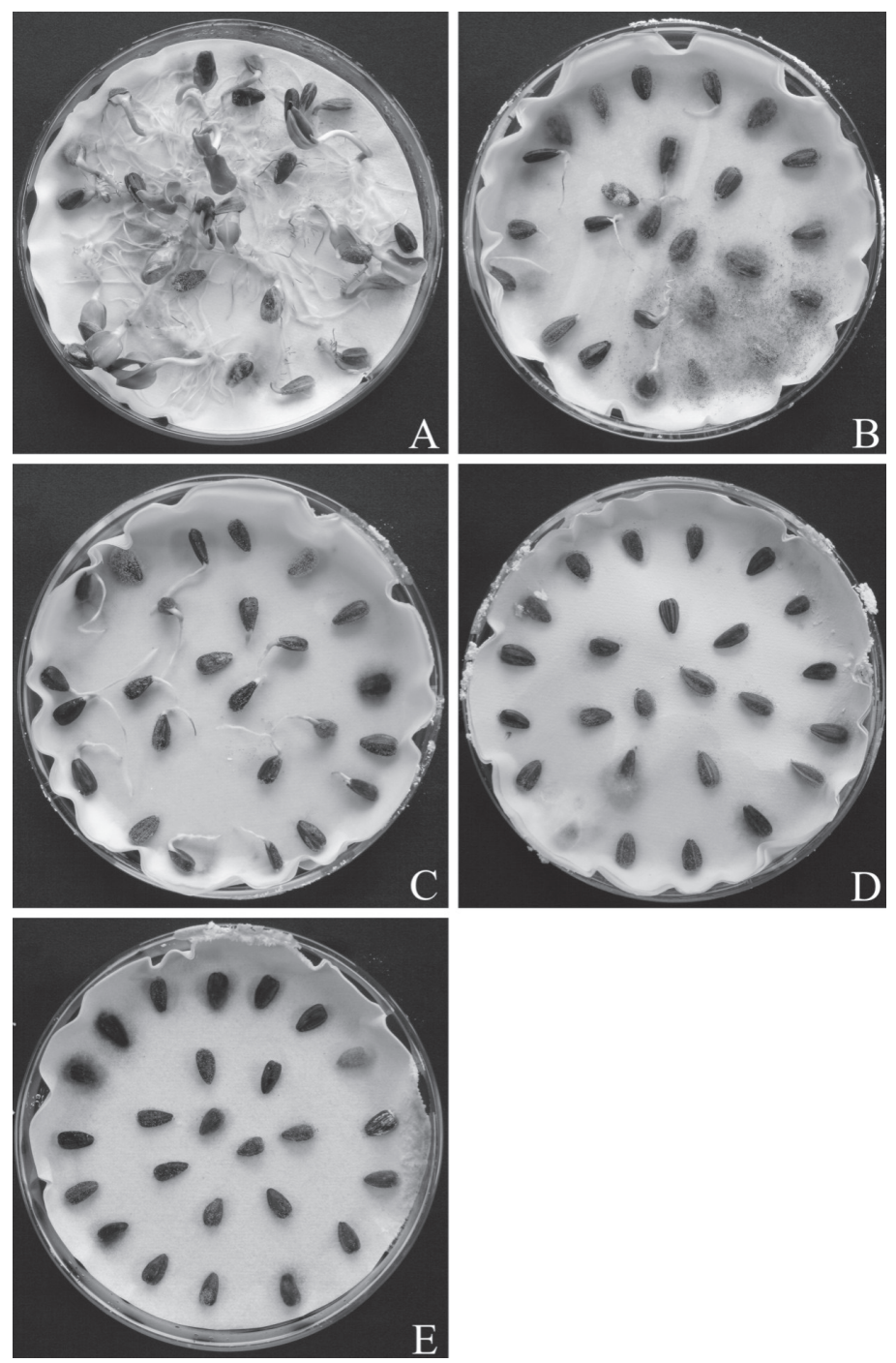

FIGURE 2 - Sunflower seed blotter moistened with distilled water (control A) and osmotic solutions prepared with mannitol at different potentials: $-0.8 \mathrm{MPa}(\mathrm{B}),-1.0 \mathrm{MPa}(\mathrm{C}),-1.2 \mathrm{MPa}(\mathrm{D})$ and -1.4 $\mathrm{MPa}(\mathrm{E})$.

A. alternata was stimulated by all osmotic solutes tested at different potentials (Figure 3 ), while mycelial growth of $A$. zinniae was stimulated by mannitol but reduced by all $\mathrm{NaCl}$ osmotic potential levels used (Figure 4). In this study, there was no effect of $A$. alternata isolates. According to earlier reports, fungal development may be stimulated at potentials varying from -0.3 to $-2.0 \mathrm{MPa}$ (Adebayo \& Harris, 1971; Wearing \& Burgess, 1979; Subbarao et al., 1993; Gao \& Shain, 1995; Whiting \& Rizzo, 1999; Carvalho et al., 2001; Farias et al., 2004; Teixeira et al., 2005; Machado et al., 2008). On the other hand, at more negative potentials than -1.0 MPa the growth of some fungi can be affected by some of the solutes used (Alam et al., 1996).

In this study the higher values of mycelial growth of A. alternata and A. zinniae on PDA amended with mannitol when compared with PDA amended with $\mathrm{NaCl}$ are probably due to the use of this sugar as an additional energy source by these fungi. Similar results were found by Machado et al. (2008) with D. oryzae, G. oryzae, P. grisea and M. phaseolina grown on PDA amended with mannitol when compared with PDA amended with $\mathrm{KCl}$ and $\mathrm{NaCl}$. Gao \& Shain (1995) also reported greater mycelial growth of $C$. parasitica on culture medium amended with sucrose as compared to medium amended with $\mathrm{NaCl}, \mathrm{KCl}$ and the mixture of the salts $\mathrm{NaCl}$, $\mathrm{KCl}$ and $\mathrm{NaSO}(5: 3: 2)$ at similar osmotic potentials. In addition, these authors attributed the differentiated growth of C. parasitica to the toxic effects of the latter salts, mainly at osmotic water potentials that were more negative than -1 MPa. Alam et al. (1996) also verified the toxic 
B.A.S. Falleiro et al.

effects of $\mathrm{NaCl}, \mathrm{KCl}, \mathrm{CaCl}_{2}$ and $\mathrm{Na}_{2} \mathrm{SO}_{4}$ (isolated and in mixtures) on the growth of A. alternata and Botrytis cinerea, in culture at osmotic water potentials that were more negative than $-1 \mathrm{MPa}$.

TABLE 2 - Mean percentage of fungi associated with sunflower seeds in seed blotter moistened with distilled water (control) and osmotic solutions prepared with $\mathrm{NaCl}$ and mannitol at different osmotic potentials

\begin{tabular}{|c|c|c|c|c|c|c|c|c|c|c|c|c|c|c|c|}
\hline \multirow[t]{3}{*}{ Lot } & \multirow[t]{3}{*}{ Fungus } & \multirow[t]{3}{*}{ Control } & & \multicolumn{11}{|c|}{ Osmotic potential } & \\
\hline & & & & \multicolumn{6}{|c|}{$\mathrm{NaCl}(\mathrm{MPa})$} & \multicolumn{6}{|c|}{ Mannitol (MPa) } \\
\hline & & & & -0.8 & -1.0 & -1.2 & -1.4 & Average (\%) & & -0.8 & -1.0 & -1.2 & -1.4 & Average (\%) & \\
\hline \multirow[t]{6}{*}{1} & Alternaria alternata & 32.0 & & 48.0 & 40.0 & 45.0 & 48.0 & 45.2 & & 31.0 & 49.0 & 54.0 & 34.0 & 42.0 & \\
\hline & Aspergillus flavus & 91.0 & & 90.0 & 92.0 & 95.0 & 88.0 & 91.2 & & 92.0 & 92.0 & 93.0 & 90.0 & 92.0 & \\
\hline & Aspergillus ochraceus & 54.0 & $\mathbf{A}$ & 72.0 & 80.0 & 80.0 & 68.0 & 75.0 & $\mathbf{A}$ & 64.0 & 69.0 & 66.0 & 68.0 & 66.7 & $\mathbf{A}$ \\
\hline & Botrytis cinerea & 08.0 & & 11.0 & 14.0 & 10.0 & 08.0 & 10.7 & & 11.0 & 13.0 & 07.0 & 10.0 & 41.0 & \\
\hline & Cladosporium cladosporioides & 02.0 & & 04.0 & 03.0 & 02.0 & 05.0 & 03.5 & & 03.0 & 03.0 & 04.0 & 05.0 & 03.7 & \\
\hline & Penicillium spp. & 08.0 & & 11.0 & 08.0 & 13.0 & 12.0 & 11.0 & & 13.0 & 17.0 & 15.0 & 32.0 & 19.2 & \\
\hline \multirow[t]{3}{*}{2} & Alternaria alternata & 90.0 & & 97.0 & 96.0 & 95.0 & 91.0 & 94.7 & & 91.0 & 93.0 & 93.0 & 86.0 & 90.7 & \\
\hline & Aspergillus flavus & 04.0 & B & 07.0 & 12.0 & 13.0 & 07.0 & 09.7 & B & 21.0 & 21.0 & 18.0 & 13.0 & 18.2 & A \\
\hline & Cladosporium cladosporioides & 09.0 & & 20.0 & 24.0 & 15.0 & 22.0 & 20.2 & & 24.0 & 31.0 & 24.0 & 40.0 & 29.7 & \\
\hline \multirow[t]{5}{*}{3} & Alternaria alternata & 27.0 & & 41.3 & 48.0 & 49.0 & 44.0 & 45.6 & & 50.0 & 40.0 & 61.3 & 56.0 & 51.8 & \\
\hline & Aspergillus flavus & 69.0 & & 81.3 & 95.0 & 88.0 & 79.0 & 85.8 & & 79.0 & 89.0 & 85.3 & 96.0 & 87.3 & \\
\hline & Aspergillus glaucus & 06.0 & B & 05.3 & 09.0 & 07.0 & 07.0 & 07.1 & $\mathbf{A}$ & 03.0 & 02.0 & 02.7 & 04.0 & 03.0 & $\mathbf{A}$ \\
\hline & Aspergillus ochraceus & 38.0 & & 44.0 & 54.0 & 61.0 & 48.0 & 51.7 & & 47.0 & 48.0 & 44.0 & 52.0 & 47.8 & \\
\hline & Botrytis cinerea & 02.0 & & 06.7 & 07.0 & 08.0 & 05.0 & 06.7 & & 01.0 & 06.0 & 05.3 & 04.0 & 040 & \\
\hline
\end{tabular}

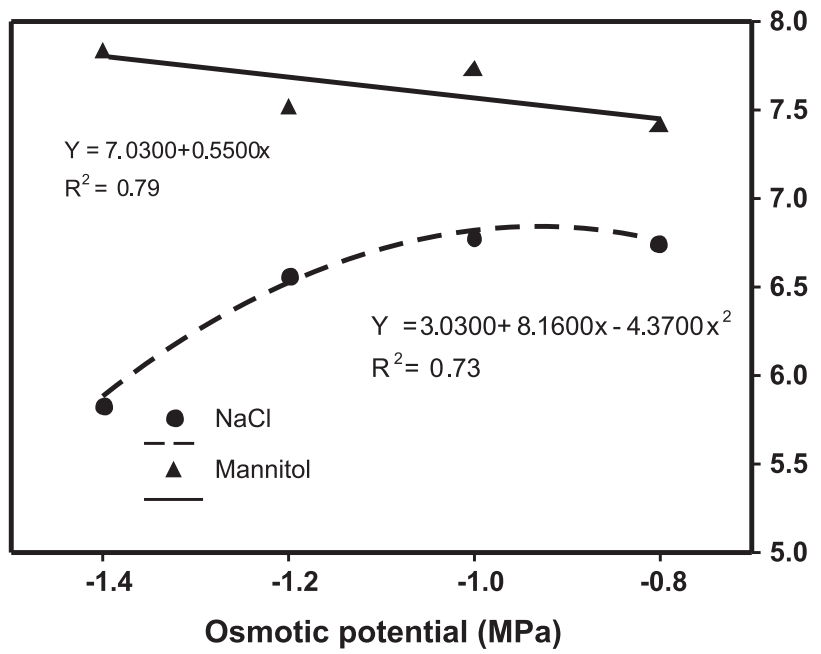

FIGURE 3 - Mycelial growth of Alternaria alternata on PDA medium amended with $\mathrm{NaCl}$ and mannitol at different osmotic potentials. 

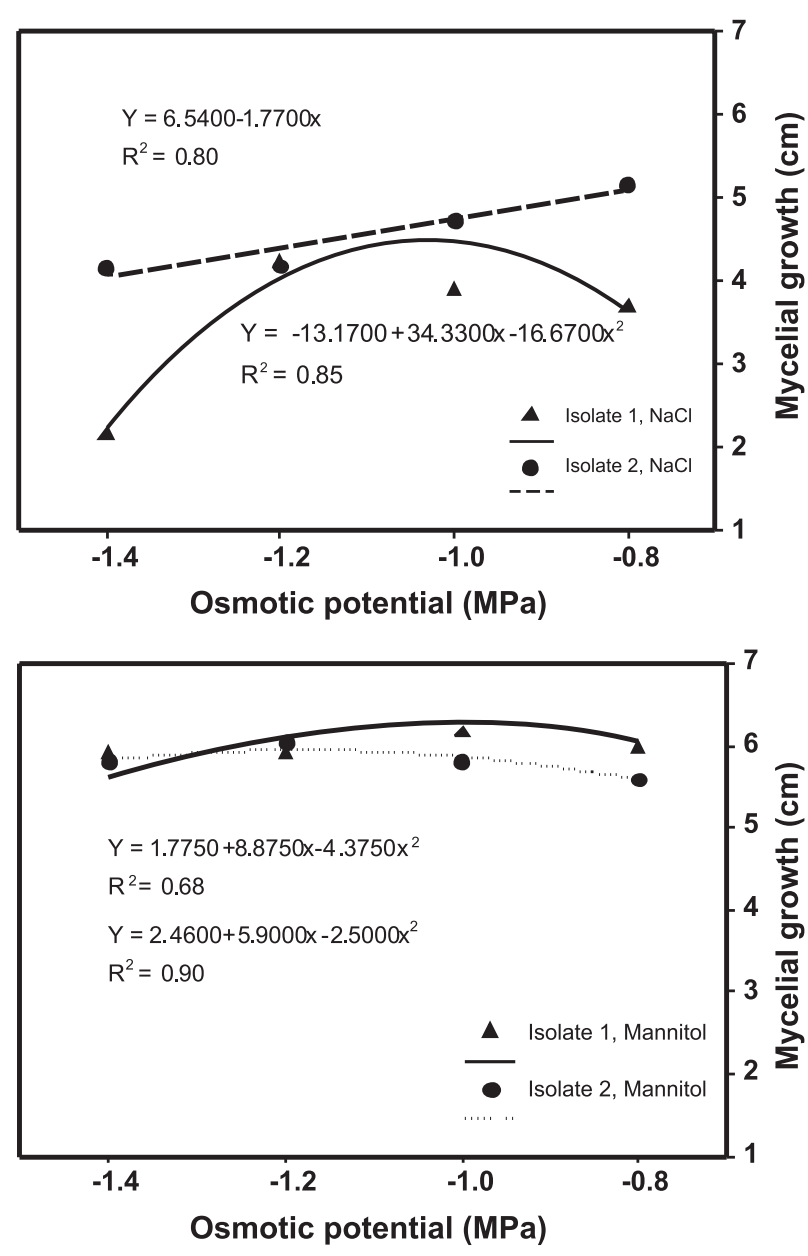

FIGURE 4 - Mycelial growth of Alternaria zinniae isolates on PDA medium amended with $\mathrm{NaCl}$ and mannitol at different osmotic potentials.

\section{REFERENCES}

Adebayo AA, Harris RF (1971) Fungal growth responses to osmotic as compared to matric water potential. Soil Science America Proceedings 35:465-469.

Adegbuyi E, Cooper SR, Don R (1981) Osmotic priming of some herbage grass seed using polyethylene glycol (PEG). Seed Science and Technlogy 9:867-878.

Alam S, Joyce D, Wearing A (1996) Effects of equilibrium relative humidity on in vitro growth of Botrytis cinerea and Alternaria alternata. Australian Journal of Experimental Agriculture 36:383-388.

Bewley JD, Black M (1994) Seeds: physiology of development and germination. $2^{\text {nd }}$ Ed. New York. Plenum Press.

Braccini AL, Ruiz HA, Braccini MCL, Reis MS (1996) Germinação e vigor de sementes de soja sob estresse hídrico induzido por soluções de cloreto de sódio, manitol e polietileno glicol. Revista Brasileira de Sementes 18:10-16.

Campos IS, Assunção MV (1990) Estresse salino e hídrico na germinação e vigor do arroz. Pesquisa Agropecuária Brasileira 25:857-862.
Carvalho JCB, Machado JC, Vieira MGGC (2001) Crescimento micelial de Colletotrichum lindemuthianum em relação à restrição hídrica do substrato agarizado. Ciência e Agrotecnologia 25:999-1005.

Coutinho WM, Machado JC, Vieira MGGC, Guimarães, RM, Ferreira, DF (2001) Uso da restrição hídrica na inibição ou retardamento da germinação de sementes de arroz e feijão submetidas ao teste de sanidade em meio agar-água. Revista Brasileira de Sementes 23:127-135.

Farias CRJ, Del Ponte EM, Dal Magro T, Pierobom, CR (2003) Inibição de germinação de sementes de trigo e milho em teste de sanidade em substrato de papel. Revista Brasileira de Agrociência 9:141-144.

Farias CRJ, Del Ponte EM, Correa CL, Pierobom CR (2004) Crescimento radial de Bipolaris sorokiniana em resposta à indução de restrição hídrica por solutos osmóticos em meio agarizado. Revista Brasileira de Agrociência 10:457-460.

Gao S, Shain L (1995) Effect of osmotic potential on virulent and hypovirulent strains of the chesnut blight fungus. Canadian Journal of Forest Research 25:1024-1029.

Hagborg WAF, Warner GH, Philips GH (1950) Use of 2,4-D as a inhibition of germination in routine examination of beans for seed-borne infection. Science 111:91.

Machado JC (1988) Patologia de sementes: fundamentos e aplicações. Lavras MG. ESAL/FAEPE.

Machado JC, Oliveira JA, Vieira MGGC, Alves, MC (2003) Controle da germinação de sementes de soja em testes de sanidade pelo uso da restrição hídrica. Revista Brasileira de Sementes 25:77-81.

Machado AQ, Machado JC, Vieira MGGC, Cassetari Neto D, Souza MV (2007) Potencial do uso da restrição hídrica em testes de sanidade de sementes de algodoeiro. Fitopatologia Brasileira 32:408-414.

Machado JC, Coutinho WM, Guimarães RM, Vieira, MGGC, Ferreira DF (2008) Use of osmotic solutes to control seed germination of rice and common bean in seed health blotter tests. Seed Science and Technology 36:66-75.

Michel BE, Radcliffe D (1995) A computer program relating solute potential to solution composition for five solutes. Agronomy Journal 87:126-130.

Neergaard P (1979) Seed pathology. $2^{\text {nd }}$ Ed. London. MacMillan.

Sommers LE, Harris RF, Dalton FN, Gardner WR (1970) Water potential relations of three root-infecting Phytophthora species. Phytopathology 60:932-934.

Subbarao KV, Michailides TJ, Morgan DP (1993) Effects of osmotic potential and temperature on growth of two pathogens of figs and a biocontrol agent. Phytopathology 83:1454-1459.

Taiz L, Zeiger E (2004) Fisiologia vegetal. Porto Alegre. Artmed.

Teixeira H, Machado JC, Oride D, Alves MC, Noda, A (2005) Técnica de restrição hídrica: Efeito sobre Acremonium strictum, protusão de sementes e obtenção de sementes de milho infestadas. Fitopatologia Brasileira 30:109-114.

Van der Moezel PG, Bell DT (1987) The effect of salinity on the germination of some Western Australian Eucalyptus and Malaleuca species. Seed Science and Technology 15:239-246. 
B.A.S. Falleiro et al.

Wearing AH, Burgess LW (1979) Water potential and the saprophytic growth of Fusarium roseum "graminearum". Soil Biology and Biochemistry 11:661-667.

Wenkert W, Lemon ER, Sinclair TR (1978) Leaf elongation and turgor pressure in field; grown soybean. Agronomy Journal 70:761-764.
Whinting EC, Rizzo DM (1999) Effect of water potential on radial colony growth of Armillaria mellea and A. gallica isolates in culture. Mycologia 91:627-635.

TPP 76 - Received 10 February 2010 - Accepted 20 December 2010 Section Editor: Jose da Cruz Machado 